\title{
Forms of Human Violence Exacerbated in the COVID-19 Pandemic Period: Theoretical Approaches and Conclusions of Current Studies
}

\author{
Bara Georgeta \\ University of Oradea, Faculty of Socio-Human Sciences, ROMANIA \\ Doctoral School of Sociology
}

Received: 2 April 2020 • Accepted: 7 June 2020 • Published Online: 16 July 2020

\begin{abstract}
Human violence is, above all, a recurring theme of contemporary societies, a worrying phenomenon that requires the prevention and intervention of the society of each society. The forms of violence are more and more conditioned, and we dress in new ways and the context of the manifestation becoming a fatality with care for people everywhere coexist. Although my doctoral dissertation aims at "school violence", we cannot ask ourselves, take care to restrict their limits, of social control, poverty and frustration to accumulate the emergency period and social control, the institution in Romania must pandemic Covid-19, and how will the psychosocial impact be addressed at this time in terms of social relations and social lives. We approach in this paper the theoretical aspect and to supervise information about the scientist of this subject. We will capitalize on this material on some recent, careful international studies and information that attest to domestic violence and can be created over time during quarantine, and the poverty line is reached by vulnerable groups is the premise for many delicate, which can already be discovered.
\end{abstract}

Keywords: violence, pandemic, risk factors, vulnerable groups, crime.

\section{Introduction}

Human violence is a complex phenomenon, which has psychological, social, cultural, and economic determinations highlighted by the extent of its forms of manifestation and the interrelationships it entails. Beyond the diversity of the phenomenon of human violence, both at the national and global levels, its dimensions require, as a first step, its knowledge, and the establishment of conceptual, thematic, and operational categories, indispensable for an integrated approach.

In contemporary society, violence and vandalism are the most common forms of aggression, with an upward trend in recent decades, in terms of quantity but also their severity, both among children, and adults, with implications that affect all social categories, regardless of the age or social status of those involved. Thus, the phenomenon of human violence has been at the center of recent concerns of politicians, opinion leaders, journalists, teachers, and especially, for researchers in various fields of social sciences. The current social situation requires an analysis of how certain forms of violence manifested themselves more virulently during the COVID

(C) Authors. Terms and conditions of Creative Commons Attribution 4.0 International (CC BY 4.0) apply. Correspondence: Bara Georgeta (PhD student), University of Oradea, Faculty of Socio-Human Sciences, Doctoral School of Sociology, Oradea, ROMANIA. E-mail: georgeta_bara@yahoo.com. 
pandemic 19 and how the psychosocial impact of the moment on the quality of relationships and social life of young people will be reflected.

\section{Defining the concept of violence}

Regarding the definition of the concept of violence, we do not find a consensus of researchers in the literature. The World Health Organization defines violence as the intentional use of force or power, actual or in the form of threats, against oneself, another person or against a group or community that results in or is highly likely to result in injury, death, psychological impairment, developmental impairment or deprivation.

The literature operates with different definitions, some depending on the severity of the forms of manifestation (Ferreol \& Neculau, 2003) or the types of violence encountered (Chesnais, 1981) or the manifestations of these violent behaviors, or the criteria by which they are distinguished (Debarbieux et al., 1999), or the factors that contribute to their onset (Floro, 1996).

Chris Gittins (2004) discusses three definitions of violence: first, it refers to the definition of violence in the ENCARTA (1999) dictionary, which refers to the use of physical force to injure or destroy something. Another definition refers to the illegal use of unjustified force, as well as the effect created by the threat; the definition used by D. Olweus (1993) according to which violence or violent behavior is aggressive behavior in which an individual uses his body or object, including a weapon, to strike or cause discomfort to an individual. Many opinions (Bujdoiu, 2001, Allen \& Anderson, 2017) argue that violence is relative because it relates to and depends on the social, legal, and political codes existing in the society in which it manifests itself. Violence is more about culture, education, context, and the qualification of a fact as violent depends largely on the social conventions in force at that time (Banciu, 2005; Benbenishty \& Astor, 2005; Berindei, 2006; Baciu, 2011). However, it is found that there are populations, communities that almost do not know the violence, while others are quite violent. Violence is a slippery term that covers a very wide range of situations, and most changes the physical, emotional, symbolic situations, practices and relationships, but it is also a controversial term (Allen \& Anderson, 2017).

Researchers and practitioners use different terms in their descriptions of violent incidents, such as aggression, violence, and intimidation (Boncu, 2004; Allen \& Anderson, 2017), and sometimes they use these terms alternately (Astor, Benbenishty, Pitner \& Zeira, 2004).

The term aggression comes from the Latin adoration, which means "to go to ...", and was later used as aggression, meaning "to go to, to attack". Subsequent attempts to explain aggression converge towards that destructive and violent behavior by which one tends or intends to harm another, destroy him, coerce him, etc. (Popescu-Neveanu, 1978; Laplanche \& Pontalis, 1994; Baron, 1977). Aggression as a concept, occurs in different contexts, being used both to describe an attitude or a certain type of personality, and to characterize certain behaviors, or as an impulsive or instinctual expression, but without having, directly, conscious control. Frequently, in the life situations of children and adults, aggression is encountered permanently or periodically, taking the form of quarrels, vandalism, or images in the media, appearing both as aggressors and victims, or in quality of witnesses.

The notion of violence comes from the Latin dream, meaning "force", meaning power, physical force, used to dominate a person. Violence must be differentiated from aggression (Allen \& Anderson, 2017), a more general type of hostile behavior that can be physical, verbal, or passive, constantly manifested in different social environments, including the school environment. However, it is difficult to differentiate between the two concepts of aggression and violence. M. Floro (1996) tried such a differentiation, using three criteria: the functional, topological, and ethical criteria. The unprecedented expansion of social networks has moved this traumatic 
phenomenon for children and adolescents in the virtual environment (Velicu, 2014; Velicu \& Blaya, 2018).

\section{Types and forms of violence}

Violence takes different forms, depending on times, places, circumstances, designating completely different realities. Violent behaviors are ubiquitous in contemporary society and include a variety of forms of manifestation in different areas of society, being classified according to the degree of involvement of actors, the relationships between them, generators, means used and objectives pursued. At the same time, it has been constantly enriched with new, more, and more complex forms.

The World Health Organization (Krug et al., 2002: 5) identifies three major forms of violence: collective violence (which includes acts of terrorism, organized crime, etc.), intrapersonal (suicidal behavior, self-harm), interpersonal violence (domestic, family or partner violence, or community violence).

J. Galtung presented in 2002 at an interdisciplinary meeting of UNESCO experts (Bonea, 2015: 192) a classification of violent acts grouped into two categories: the first category includes aggressive, defensive, deliberate and involuntary violence, and the second category concerns intrapersonal, interpersonal, intergroup and intersocial violence.

The concept of violence is found in a multitude of forms in society, it is determined by certain factors related to the education of individuals, access to information resources and their evolution in today's society, their mentality and interests in society, political trajectory, religiosity, changes in the family, personal experiences that make their mark on behavior (Sandu, 2008; Bonea, 2015; McMahon, Martinez, Reddy, Espelage \& Anderman, 2017a).

Drăgănescu (2018) distinguishes the typological situations related to both individual and collective violence, as well as the three categories of factors that generate these types of violence. Numerous researchers (Neculau \& Ferreol, 2003; Liiceanu, 2003; Allen \& Anderson, 2017, Nielsen \& Einarsen, 2018) considered it necessary to distinguish between private and collective violence. The private one includes both criminal violence, which includes the three types: deadly violence (murders, murders, executions), bodily violence (beatings and bodily harm), and sexual violence, as well as non-criminal violence, which refers to suicide / suicide attempts and accidents. The second category is collective violence in three subcategories: the violence of citizens against power (acts of terrorism, strikes, and revolutions), the violence of power against citizens (state terrorism, industrial violence) and paroxysmal violence (war) (Neculau, 2003: 6).

It is found that modernity and the urban environment have produced changes in the values and aspirations of individuals, generating new forms of violence. Lack of education, poverty, poor information have led to contexts in which violence has become a tolerated behavior, even accepted, which gradually became natural and frequent (Liiceanu, 2003: 47). We notice today that there is a rich phenomenology of violence that requires increased attention from the social body and policymakers. In addition to the known forms of violence - physical violence, psychological, sexual, economic and social violence - enshrined in the literature, modern life has brought to attention new forms of violence in the reality of the present: bullying - psychological violence, cyberbullying - internet violence, mobbing - discrimination and harassment in the workplace, drug-related violence, trafficking in human beings, urban violence, school violence, sexual violence, economic violence, social violence (Cace, 2010; Bonea, 2019; Perkins \& Barry, 2020). 
Other authors have classified violence based on the analysis of the source that generates it, thus distinguishing between proactive violent behavior (when subject to a purpose) and reactive (Crick \& Dodge, 1994, according to Benga \& Opre 2015).

School violence, as a form of violence manifested in contemporary society, is strongly encountered in school life, taking different forms: from verbal and psychological violence (insults, threats, insults, teasing) to physical violence (beatings, fights), degradation of goods (written on walls, broken windows, damaged furniture), refusal to work, absenteeism, disruption of courses and even theft, assaults with weapons, sexual violence, drug use (Axinte \& Sorici, 2015). Sociological studies show that, lately, there is a sharp increase in delinquent manifestations. Thus, it is observed the shift of the share of antisocial acts, from older age groups to smaller groups; exceeding the limit from which we can characterize an antisocial act committed by a minor only as deviant or pre-delinquency; emphasizing the seriousness of crimes committed by adolescents (crimes such as murder, robbery, rape); the alarming increase of the recidivism phenomenon among some categories of adolescents (Bujdoiu, 2001: 89). We distinguish here between "evasions behaviors", i.e. those more common forms of school deviance, categorized as "disguised defenses", such as: running away from school, absenteeism, school dropout, drug addiction, suicide, etc. and "open defenses", respectively the most common forms such as vandalism and violent behavior. Of course, each of them is generated by a specific causality and manifests itself in different conditions, individually or collectively (Neamțu, 2003: 180; Sălăvăstru, 2003: 129; Drăgănescu, 2018: 427).

The phenomenon of violence has been and still is studied and analyzed differently from one society to another, in terms of different theses, guidelines and explanatory theories that complement or exclude each other, but each, seeking to identify the causes and mechanisms that determine these behaviors.

\section{Causes of human violence}

Recent studies consider that the most common situations in which we encounter patterns of violent behavior are: family, social environment, and media (Sălăvăstru, 2003; Bonea, 2015; Velicu \& Blaya, 2018; Stonard, 2020). Analyzing the first category, most studies conclude that when violence is practiced in the family or children are victims/witnesses of domestic violence and they will become violent; it is seen that children from families in which both parents were raised with the help of corporal punishment become violent. Violent acts often occur when the street becomes a friendlier place than family for many abused and abused children (Hagan \& McCarthy, 1998). Another category of causes is related to the social environment, supported by the literature (Baciu, 2011; Drăgănescu, 2018), which attests that, in those communities where aggressive behavior patterns are accepted, even admired, aggression is easily transmitted to next generations. A multitude of studies is currently part of the violence generated by the media (Velicu, 2006, 2014; Velicu \& Blaya, 2018, Stonard, 2020), pointing out that, in particular, television broadcasts daily cases of aggressive physical and verbal behavior, sexual and psychological.

In general, violence is largely associated with difficult urban areas, where misery and poverty predominate (Hagan, 1998). Therefore, numerous studies (Dascălu \& Singh, 2012; Cace, 2010; Drăgănescu, 2018; Perkins \& Barry, 2020) attest as favorable sources of violence, the family factor, the social factor, and the individual factor.

Regarding the family factor, it is considered that the genesis of deviance is the education received in the family. Newer research, conducted to establish the role of the family in the etiology of deviance, has identified a variety of causal factors such as socialization, emotional climate, family cohesion, economic and cultural status, etc. (Sandu, 2008; Cace, 2010; Bonea, 2019). Regarding the individual factor, it is seen that they are constituted in two categories: constitutional factors, related to the hereditary dowry and the neuro-psychic structure and the 
particularities of the individual's personality (Boncu, 2004; Baciu, 2011; McMahon et al., 2017a; Drăgănescu, 2018; Nielsen \& Einarsen, 2018).

Referring to the social factor, it is believed that it offers many sources of influence that can induce, stimulate, and maintain violence. Thus, social inequalities, the economic situation, the media, the diminution of social control mechanisms, the crisis of moral values, dysfunctions at the level of the factors responsible for the education of young people, the lack of cooperation of the institutions involved in education. At the societal level, we distinguish economic causes, sociocultural or religious causes, psychological or pedagogical causes (Neamțu, 2003: 210). Studying the phenomenon of violence in schools, we appreciate based on theoretical considerations and research findings, provided by the literature, that this behavior is based on several groups of causes: psycho-individual causes, respectively, certain characteristics of individuals who associate with violent behaviors, such as: low tolerance for frustration, difficulties in adapting to school discipline, negative self-image, emotional instability, lack or insufficient development of self-control mechanisms, tendency to addictive behavior, poor empathic ability; family causes, such as: socio-affective climate (tense relationships between parents, violent attitudes of parents towards the child, environment without emotional security); family type (origin of students from disorganized families); economic conditions of the family (insufficient income); family size (large number of children in the family, a situation that often involves the accentuation of the phenomenon of poverty); low level of education of parents; another category is represented by school causes, materialized in: difficulties of student-teacher communication, imposing the authority of teachers, excessively authoritarian teaching styles, distortions in student evaluation, teachers 'prejudices regarding students' ethnicity, age, as well as his teaching experience, busy school curricula (Boncu, 2004; Astor, Benbenishty, Pitner \& Zeira, 2004; Perkins \& Barry, 2020); Causes induced by the social context: mass media (Velicu, 2014; Velicu \& Blaya, 2018; Bonea, 2019) which, through the values they promote, as well as through the consequences on the way of spending free time, greatly influences the behaviors of young people, offering models aggressive behavior or violence, through movies, video games or programs with aggressively promoted content; the influence of the group of friends and the entourage outside the school, the "neighborhood gangs" the disadvantaged areas, the peripheral neighborhoods of the cities (Hagan, 1998), with all the characteristics that some of them have a major influence on the behaviors of young people.

Most researchers seem to agree that violence is multicausal (Nielsen \& Einarsen, 2018; Potâng \& Botnari, 2018; Stonard, 2020), which means that no factor - viewed separately, is responsible for violent behavior.

The specialized literature concludes with a quasi-unanimity of opinions that aggression has at its origin multiple causes, social, psychological, medical, etc. (Nielsen \& Einarsen, 2018; Potâng \& Botnari, 2018). It is unanimously acknowledged that the main reasons are associated with numerous risk factors (external or internal), identified at the individual, family, school, group of friends, community, or society. These risk factors act during the life of the individual until the moment of committing the violent act (Balica, 2008). There are also a series of situational factors that influence the production of the violent act, related to the relationship between the victim and the aggressor, the ways of producing violent acts, etc.

All psychological approaches claim that the motivating processes involved in the deviant act are based on a causal determination generated by the mismatch between requirements and possibilities. Motivation sums up many component factors: impulses, stimuli, intentions, tendencies, etc. The frustrations resulting from the gap between requirements and possibilities lead to an internal or motivational instigation, to aggression (Dobrescu, 2010: 47). The reasons for deviant behavior can be both "exogenous", having an external source exerted by social influence, and "endogenous", intrinsic. Studies and research focused on these theories have shown 
that psychiatric disorders are involved in the personality of individuals, respectively in the orientation of antisocial behaviors.

Both the risk factors and the causes that determine violence, identified in the literature or by contemporary sociological and psychological theories, attest to the fact that young people who have such models (family, social environment, etc.), will show violent behaviors about to the others.

But frustrations can be possible, often noticed and important condition for the manifestation of aggressive behavior (Dollard, Doob, Miller, Mowrer \& Sears, 1939). Avoiding feelings of frustration, on a personal and social level, can also mean avoiding aggression.

5. Forms of violence exacerbated during the pandemic: Conclusions of national and international studies and reports on the social effects of the coronavirus pandemic (Covid-19) on the individual and the manifestations of violent behavior

According to the report "Pandemic and standard of living. Social protection policies" published on 25 April 2020, by the Quality of Life Research Institute and the National Institute of Economic Research, Costin C. Kiritescu, Romanian Academy, among the national social effects caused by the coronavirus pandemic are the economic crisis that produces effects socially, effects that are already being felt and will be visible in the immediate and medium-term. It can be seen here that this economic crisis has implications for the individual and the fight against the spread of the pandemic has an obvious effect on his standard of living, the occurrence of crimes specific to the period, and the limitation of social control. The incomes of the population decreased being affected by the pandemic, during which time most citizens were unable to carry out their daily work, having limited opportunities to work from home and to take care of the needs of family and children. The degradation of the quality of life of the population appears in time and the socioeconomic consequences will be highlighted in the coming years. The most affected groups, classified as vulnerable, target people who have lost their jobs through layoffs entering technical unemployment, those who have recently returned to the country, who have worked abroad and are left without income, as well as those without occupation; represent those made redundant who are not eligible for unemployment, as well as the poor who are not eligible for the guaranteed minimum income/emergency aid, or those who lived off agriculture. The social protection system, although in continuous evolution in the last 30 years (Marin \& Stănculescu, 2019), is insufficiently developed to deal with social events of the magnitude of a pandemic.

The establishment of quarantine with specific measures of social and physical distance and the restriction of the rights of the movement of persons was a real attempt to maintain a balanced mental state. Against the background of the frustrations accumulated during this period and the precarious financial situation, the crimes manifested themselves mainly in the sphere of intra-family relations, increasing the number of domestic violence and in the economic-financial sphere appearing new forms of crime such as trafficking in medical equipment and products, smuggling of immigrants, theft, fraud through telephony and cyberbullying, cybercrime (source: Interpol, Europol). Regarding domestic violence, many states (Germany, France, Spain, Argentina, Canada, etc.) have reported an increase in aid requests from their victims by over 3040\% (Cyprus, Singapore, Australia).

In the context of the measures caused by the SARS-CoV2 pandemic, specialists in education and political and social sciences in Romania claim that students from disadvantaged backgrounds do not have equal opportunities in education, because they do not have the means to learn online. Specialists (Florian et al., 2020) think believe that they are the most exposed in the context of the pandemic, being included in the groups with the highest degree of vulnerability. 
Studies show that in rural areas, cases of poverty and social exclusion are more common. They specify that, according to Eurostat, in 2019 the early school leaving rate was $15.3 \%$ nationally and 22.4\% in rural areas. In Romania, 32.5\% of the population is at risk of poverty or social exclusion: a percentage of $57.6 \%$ of families with more than two children but also $48.8 \%$ of single-parent families with dependent children are at risk poverty or social exclusion; Regarding the percentage of children under 16 , it is $37.9 \%$ and the percentage of young people aged 16-24 who are at risk of poverty or social exclusion is $37.4 \%$ (Florian et al., 2020). The results of numerous studies show that young people who are neglected and abused are also less likely to engage in school work and more likely to conflict with teachers. Moreover, neither the school nor the young people on the street can specify exactly what is the influence of certain factors, namely whether these risk factors or triggers, such as the family situation, are a disadvantage for those from disorganized families, for whom the street represents an environment conducive to committing crimes (Hagan \& McCarthy, 1998: 78).

Recent studies show that behavioral changes in children in pandemics were evident with the introduction of the quarantine regime. Behavioral changes in children, reported by parents in the pandemic target manifestations such as defiance, frequent conflicts between siblings and increased jealousy, anger and hostility, irritability, difficulty concentrating, sleep, low motivation and productivity, disorganization, pessimistic thoughts, anxiety, refusal to do something, frequent and explosive nervous breakdowns, excessive desire for validation, spending time in front of the TV screen.

One of the most famous psychologists in Romania, Mircea Miclea, professor at the Faculty of Psychology and Educational Sciences at Babeș-Bolyai University, researcher, founder of the cognitive school in Romanian psychology, former Minister of Education in Romania, speaking in an interview about the traces left by the 2 months of isolation, states that although she is not aware, the signs of anxiety (hypersensitivity and hyper-reactivity) will be obvious and estimates that in the long run, about 8-10\% will have a post-traumatic stress disorder, respectively an intensification and a chronic state of anxiety or depression.

The World Vision study conducted in 2020 included 101 children and young people aged between 8 and 17 from 13 in several countries: Romania, Albania, Bangladesh, Bosnia and Herzegovina, Brazil, Democratic Republic of Congo (DRC), Mali, Mongolia, Nicaragua, Peru, Philippines, Sierra Leone, and Syrian refugee children living in refugee camps near the TurkishSyrian border and highlighted that the feelings felt during this period by the children and adolescents interviewed are emotional stress, anxiety, anger, uncertainty, and concern and that three major factors such as school closures, social distancing, and growing poverty had an impact on children's emotional well-being. The study found that more than $91 \%$ of children and adolescents felt stressed or experiencing disturbing experiences due to the COVID-19 pandemic, while $75 \%$ of children and adolescents found it emotionally difficult to cope against the restrictions of physical and social distancing. In many of the countries in this study, neither students nor teachers were prepared to switch to online education: not all children have access to the Internet, teachers were not prepared for online education, students in the most disadvantaged communities Vulnerable people are discriminated against during this period, and social distancing measures, although important for protection against the new coronavirus, have led respondents (75\%) to find it emotionally difficult to cope with restrictions. Thus, among the negative consequences of the restrictions that affected them are "loneliness, lack of collaboration, teamwork, changes in diet or sleep, limited internet access in some communities." Adolescents say they want to help fight the spread of COVID-19 and get involved in raising awareness about the importance of protective measures against the spread of the virus.

In the study "School in an emergency state. The access of school children in Romania to online education", made by the Romanian Institute for Evaluation and Strategy, in April 2020, shows that only $68 \%$ of respondents have dedicated access to at least one device (desktop, laptop, 
tablet) and even if the percentage related to the existence of the internet in the household is quite high (93\%), with a fairly strong connection (85\%) the percentage is discrepant when comparing data from rural to urban areas.

The survey on parents' perception of online education, during the state of emergency, conducted between 29 April and 6 May 2020, by the National Federation of Associations of parents in pre-university education, which investigated how students perform activities online learning, had 4,852 respondent parents, mostly from urban areas (81.2\%). They believe that online education cannot replace face-to-face education at school (80.1\%) and only $19.9 \%$ of respondents believe that this type of interaction can replace classical education.

Regarding domestic violence before the outbreak of the pandemic, the data published in the Activity Report of the Public Ministry for 2019, show that, in Romania, six out of 100 defendants sent to trial are minors; daily, prosecutors sue 11 minors, one of whom is under arrest. As a percentage, out of 100 criminals, 2.4 commit domestic violence. The data show that aggressions between spouses and those against parents, or against their children, reach alarming levels.

\section{Discussions and reflections}

In the context of the COVID pandemic 19, we are witnessing a reversal of the value grid of humanity, thus enhancing the perfect opportunity to trigger personal anxieties. The literature argues that the reasons, circumstances, and causes that usually lead to aggressive behavior are multiple (Tutty, 2005; Tower, 2006): these can be economic, political, social, psychological, biological, relational, communicative, and contextual. However, we cannot generalize or say that only families with large financial problems, with a low level of education, or those who live on the outskirts of the city are aggressive families. Also, we cannot say that all those who experienced childhood violence (as witnesses or as victims) will practice such behaviors in adulthood. However, numerous studies conclude that the frequency of domestic violence between partners is higher in poor families, with many children, with a low level of education, where, usually, a lot of alcohol is consumed and parents are unemployed (Voinea, 2005; Bonea, 2016). On the other hand, like all sociological and psychological theories attest, domestic violence leaves its mark on the development of young people and the manifestation of violent behaviors. According to Bandura (1977), we can say that minors are prone to imitate the behavior of parents and adults in general.

It remains to investigate how the pandemic influenced aggressive behavior and what medium and long-term effects this influence will have and how the psychosocial impact of the moment on the quality of relationships and social life in the next period will be reflected. My future research will also focus on the consequences of restrictions, social control, poverty, and frustrations accumulated during the state of emergency and social control, established in Romania due to the COVID-19 pandemic on social behavior in schools.

\section{Conclusion}

In the constructive approach to violent behavior, concern for aggression is one of the key factors. Understanding what determines such behavior contributes greatly to identifying the best ways to intervene in such cases. The specialized literature, through the elaborated theories, attests that aggression is manifested either in the form of accentuated and frequent fits of anger or in the form of violent behaviors or accentuated impulsivity. In explaining intergroup conflicts, sociological theories are the ones that have great relevance, and psychological and psychosocial ones gain more weight in the interpretation of intrapersonal and interpersonal conflicts. 
Violence has several negative effects on those who witness or experience it, and children are especially sensitive to their harm. The general situation is worrying, as violence has now become an issue facing all societies, which requires a whole-of-society position and the development of strategies for investigation, prevention, and control. Fortunately, many studies have provided solid arguments for the development of educational and social programs that have advocated for the promotion of nonviolent means of interaction and regulation of social life and thus, various programs have begun to be applied with positive results in some states, succeeding. to prevent and reduce this phenomenon.

\section{Acknowledgements}

Paper funded by Project 123008, "SmartDoct - High-quality programs for doctoral students and postdoctoral researchers of the University of Oradea to increase the relevance of research and innovation in the context of the regional economy", a project funded by the Operational Program Human Capital 2014-2020.

The author declares no competing interests.

\section{References}

Allen, J. J., \& Anderson, C. A. (2017). Aggression and violence: Definitions and distinctions. In P. Sturmey (Editor-in-Chief), The Wiley Handbook of Violence and Aggression. John Wiley \& Sons Ltd. Published 2017 by John Wiley and Sons, Ltd. https://doi.org/10.1002/9781119057574.whbva001

Astor, R. A., Benbenishty, R., Pitner, R., \& Zeira, A. (2004). Bullying and peer victimization in schools. In P. A. Meares \& M. W. Fraser (Eds.), Intervention with children and adolescents: An interdisciplinary perspective. Boston: Pearson.

Axinte, G., \& Sorici, C. (2015). Prevenirea violenței în școală - resurse pentru școli și profesori. Ghid pentru profesori, învăţători și educatoare, material elaborat prin Proiect finanţat de Comisia Europeană prin Programul Erasmus +, Acțiunea Cheie 1.

Baciu, Gh. (2011). Agresivitatea umană şi actele de violență umană în aspect medico- socio-juridic. Revista Institutului Național al Justiției, nr. 3, din 2011.

Balica, E. (2008). Criminalitatea violentă. Bucureşti: Editura Oscar Print, 315p.

Banciu, D. (2005). Crima şi criminalitatea. Repere şi abordărijuris-sociologice. Bucureşti: Editura Lumina Lex.

Baron, R. A. (1977). Human aggression. New York: Plemn.

Benbenishty, R., \& Astor, R. A. (2005). School violence in context: Culture, neighborhood, family, school, and gender. Oxford: Oxford University Press.

Benga O., Băban, A. Opre, A., (2015). Strategii de prevenție a problemelor de comportament. Cluj Napoca: Editura ASCR, ISBN: 978-606-8244-91-4.

Berindei, A. R. (2006). Criminalitatea juvenilă. Iași: Editura Lumen, ISBN: 10 973-7766-86-5; ISBN 13 978-973-7766-86-1.

Boncu, Ș. (2004). Psihologie socială, Note de curs. Comportamentul agresiv. Iași, Universitatea „Al. I. Cuza”. 
B. Georgeta - Forms of Human Violence Exacerbated in the COVID-19 Pandemic Period...

Bonea, G. V., coord. (2015), Devianţa: viziuni contemporane. Bucureşti: Editura Sigma, ISBN 978-606727-024-2.

Bonea, G. V. (2019). Agresivitatea și violența în școlile din România: Bullying și mobbying. Revista CALITATEA VIET⿱II, XXX, nr. 1, 2019, 59-75. http://www.revistacalitateavietii.ro/2019/CV-12019/04.pdf.

Bujdoiu, N. (2001) Consideraţii privind investigarea fenomenului infracţional juvenile. Societatea şi Dreptul, Editura UniSAST, Braşov.

Cace, S. (2010). Studiu asupra fenomenului de mobbying şi a unor forme de discriminare la locul de muncă în România. In S. Cace \& C. Tomescu (coord.). Bucureşti: Editura Expert.

Chesnais, J.-C. (1981), Histoire de la violence. Paris: Laffont.

Dascălu, A., \& Singh, A. (2012). Delincvența Juvenilă- Un Fenomen Social tot Mai Des Întâlnit. In Analele Universităţii “Constantin Brâncuşi” din Târgu Jiu, Seria Litere și Ştiinţe Sociale, Nr. 1/2012, pp. 107-119.

Debarbieux, E., Garnier, A., Montoya, Y., \& Tichit, L. (1999). La violence en milieu scolaire: Le désordre des choses (Vol. 2). París: ESF éditeur.

Dobrescu, M. (2010), Sociologia devianței. Colecția Orizonturi Socio-Umane, Reșița, Editura Eftimie Murgu, ISBN 978-973-1906-79-9.

Dollard, J., Doob, L. W., Miller, N. E., Mowrer, O. H., \& Sears, R. T. (1939). Frustration and aggression. New Haven: Yale University Press.

Drăgănescu, A. (2018). Violence, on element of aggravation of some categories of crime. In The $13^{\text {th }}$ Edition of the International Conference, European Integration Realities and Perspectives. ISSN: 2067-9211, pp. 425-432.

Florian, B., \& Țoc, S. (2020). Policy note: Educația în timpul pandemiei. Răspunsuri la criza nesfârşită a sistemului educațional românesc. https://media.hotnews.ro/media server1/document2020-04-29-23945977-0-2020-florian-policy-note.pdf.

Floro, M. (1996). Questions de violence violence `a l’ecole. Paris: Editions Eres.

Hagan, J., \& McCarthy, B. (1998). Mean streets. Youth crime and homelessness. Cambridge University Press 1998, ISBN 0-521-64626-X.

Krug, E. G., Dahlberg, L. L., Mercy, A. J., Zwi, A. şi Lozano-Ascenio, R. (2002). Rapport mondial sur la violence et la santé. Genève: Organisation Mondiale de la Santé.

Laplanche, J., \& Pontalis, J. B. (1994). Vocabularul psihanalizei. București: Editura Humanitas.

Liiceanu, A. (2003). Violența umană: o neliniște a societății contemporane. In G. Ferréol, și A. Neculau, Violența. Aspecte psihosociale. p. 47- Iași, Polirom, ISBN: 973-681-261-8, (336p).

Marin, M., \& Stănculescu, M. S. (2019). Evoluția sistemului de protecție a copilului în România în ultimii 30 de ani: Development of the child protection system in Romania for the past 30 years. Sociologie Românească, 17(2), 60-91. https://doi.org/10.33788/sr.17.2.3

McMahon, S. D., Martinez, A., Reddy, L., Espelage, D., \& Anderman, E. (2017a). Predicting and reducing aggression and violence toward teachers: Extent of the problem and why it matters (pp. 13351350). Hoboken, NJ: Wiley. Google Scholar.

Neamțu, C. (2003). Devianța școlară. Ghid de intervenție în cazul problemelor de comportament al elevilor, Iaşi, Editura polirom, ISBN: 973-681-403-3; index 159.922.7.

Neculau, A., \& Ferreol, G., (2003). Violența. Aspecte psihosociale. Iași: Ed. Polirom, ISBN: 973-681-261-8.

Nielsen, M. B., \& Einarsen, S. V. (2018). What we know, what we do not know, and what we should and could have known about workplace bullying: An overview of the literature and agenda for future research. Aggression and Violent Behavior, 42(2018), 71-83. www.elsevier.com/locate/aggviobeh. 
Olweus, D. (1993). Bullying at school: What we know and what we can do. Oxford, UK: Blackwell Publishers.

Parkay, F. W., \& Standford, B. H. (1992). Becoming teacher, Boston, apud Stan, E., profesorul între autoritate și putere, 1999, p. 30, Editura teora, București.

Perkins, N. H., \& Barry, J. E. (2020). Should failure to protect laws include physical and emotional sibling violence? Child and Family Social Work, 25(1). 206-209. https://www-scopus-com.am.einformation.ro/record/display.uri?eid=2-s2.0-85063982842\&origin=resultslist\&sort=plf-.

Popescu-Neveanu, P. (1978). Dicționar de psihologie. București: Editura Albatros.

Potâng, A., \& Botnari, I. (2018). Teorii explicative ale agresivității. Studia Universitatis Moldavie, 2018, nr. 5(115) Seria "Științe ale educației". ISSN 1857-2103, ISSNe 2345-1025, pp. 125-128, https://ibn.idsi.md/ro/vizualizare articol/66628.

Sălăvăstru, D. (2003). Violența în mediul școlar. In G. Ferreol \& A. Neculau (Eds.), Violenţa. Aspecte psihosociale. Iași: Polirom, ISBN: 973-681-261-8, pp. 119-137.

Stonard, K. E. (2020). Technology was designed for this: Adolescents' perceptions of the role and impact of the use of technology in cyber dating violence. Computers in Human Behavior, 105, 106211. $\quad$ https://www-scopus-com.am.e-nformation.ro/record/display.uri?eid=2-s2.085075989589 \&origin $=$ resultslist\&sort $=$ plf-

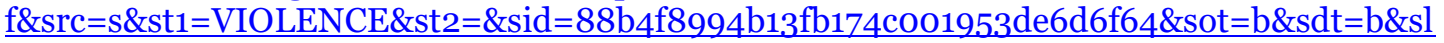
$=23 \& \mathrm{~s}=$ TITLE-ABS-KEY\%28VIOLENCE\%29\&relpos $=4 \& c i t e C n t=0 \&$ searchTerm $=$.

Şoitu, L., \& Hăvîrneanu, C. (2001). Agresivitatea în şcoală. Iaşi: Institutul European.

Tower, L. E. (2006). Barriers in screening women for domestic violence: A survey of social workers, family practitions and obstetrician-gynecologists. Journal of Family Violence, 21, 245-257.

Tutty, L. M. [1996] (2005). Cercetarea calitativă în asistenţa socială. Faze, etape şi sarcini. Iaşi: Editura Polirom (Trad. rom. Ilin, L., D.).

Velicu, A. (2014). Bullying-ul online și offline: victime versus agresori. Revista română de sociologie, serie nouă, anul XXV, nr. 1-2, 19-36, Bucureşti, 2014.

Velicu, A., \& Blaya, C. (2018). Campaniile de siguranță pe inetrnet şi prevenirea cyberbullyingului în școli, o poveste a copiilor, spusă de datele proiectului EU KIDS ONLINE. Revista română de sociologie, serie nouă, anul XXIX, nr. 1-2, p. 3-22, Bucureşti, 2018.

Voinea, M. (2005). Familia contemporană. Mică enciclopedie. Bucureşti: Editura Focus.

UN Women, Violence against women and girls: The shadow pandemic (2020). Statement by Phumzile Mlambo-Ngcuka, Executive Director of UN Women, https://www.unwomen.org/en/news/stories/2020/4/statement-ed-phumzile-violenceagainstwomen-during-pandemic.

INTERPOL (2020). The global operation sees a rise in fake medical products related to Covid-19, 19/03/2020, https://www.interpol.int/News-and-Events/News/2020/Global-operationsees-a-rise-in-fake-medical-products-related-to-COVID-19.

EUROPOL (2020). How criminals profit from the Covid-19 pandemic, 27/3/2020, https://www.europol.europa.eu/newsroom/news/how-criminals-profit-covid-19-pandemic.

Federația Națională a Asociațiilor de părinți din învățământul preuniversitar, sondaj (2020). https://stiriedu.ro/wp-content/uploads/2020/05/Comunicat-FNAP.pdf.

Raportul de activitate al Ministerului Public pentru anul 2019 (2019). https://mpublic.ro/sites/default/files/PDF/raport activitate 2019.pdf.

Miclea., M. Interviu disponibil la: https://www.edupedu.ro/mircea-miclea-despre-urmele-lasate-de-cele2-luni-de-izolare-la-nivel-de-societate-cred-ca-se-va-accentua-cultul-sigurantei-noua- 
B. Georgeta - Forms of Human Violence Exacerbated in the COVID-19 Pandemic Period...

religie/?fbclid=IwAR1sSGSuyYZoeERivZ6wvoYQZxOobu3YK3rZYMLYfTsVtAYjJHsTnIez2o.

Studio World Vision (2020). https://worldvision.ro/2020/05/07/studiu-world-vision-peste-91-dintrecopii-si-adolcenti-se-simt-stresati-sau-trec-prin-experiente-tulburatoare-din-cauzapandemiei-de-covid-19/.

Institutul pentru Cercetarea Calităţii Vieţii (ICCV) al Academiei Române (2020). Raport social al ICCV „Pandemia şi standardul de viaţă. Politici de protecţie socială” http://www.iccv.ro/wpcontent/uploads/2020/04/Raport-social-ICCV-aprilie-2020.pdf.

Institutul Român pentru Evaluare și Strategie (2020). Școala în stare de urgență. Accesul copiilor școlari din România la educație online. https://cdn.edupedu.ro/wpcontent/uploads/2020/05/ires accesul-elevilor-din-romania-la-educatie-online studiunational aprilie-2020.pdf?fbclid=IwAR11G4a6YiwkdPOEuauiorpC85H8SiXKq5QjdAeiylOSQxwQ4VWdW6KxV4. 